\title{
sciendo
}

DOI 10.2478/sbe-2020-0054

SBE no. 15(3) 2020

\section{FINANCIAL ANALYSIS OF MAJOR RETAIL CHAINS WITHIN A TURBULENT ECONOMIC ENVIRONMENT}

\begin{abstract}
ZISOUDIS NIKOLAOS
Democritus University of Thrace, Department of Agricultural Development, Greece

KARELAKIS CHRISTOS

Democritus University of Thrace, Department of Agricultural Development, Greece

THEODOSSIOU GEORGE

University of Thessaly, Department of Business Administration, Greece

\section{LOIZOU EFSTRATIOS}

University of Western Macedonia, Department of Regional Development \& Cross Border

Studies, Greece

Abstract:

The Greek economic activity has been declined dramatically in recent years as many sectors of the economy that cannot cope with the new state brought about by the economic crisis. An economic crisis can be described as the phenomenon when an economy is characterized by a continuous and noticeable decline in its economic activity. As an economic activity, we are referring to all the macroeconomic dimensions of the economy, such as employment, the national product, prices, investments, etc. The downturn in the supermarket sector, which is attributed to the country's financial situation, has led to a decline in the household disposable income. The present study was carried out at the time of the economic crisis, concerning a productive sector of the Greek economy, where millions of euros are exchanged hands. The objective of the study was to explore the impacts of the economic crisis on the sector by using a series of financial indicators. The results point to significant effects on the efficiency and earnings of the major actors of the sector.
\end{abstract}

Key words: Food retailing, economic crisis, financial indicators.

\section{Introduction}

In today's Greece, the economic crisis is one that has had many negative consequences for Greek society. In general, the economic crisis is called the phenomenon that an economy is characterized by a continuous and noticeable decline in its economic activity. When we say economic activity, we are referring to all the macroeconomic dimensions of the economy, such as employment, the national product, prices, investments, etc. The main indicator of economic activity is investments, which, when fluctuated, support them and all other economic factors (Koufaris, 2010). The economic 
crisis usually occurs when the numbers in the Gross Domestic Product (GDP) decrease and becomes more noticeable when unemployment rises, investment and production decreases demand decreases, as does consumption, mainly due to the shrink of the real income (Mankiw, 2013).

The available income based on the Greek statistical authority (Greek statistical authority HELSTAT) in 2012 was 173.2 billion euros and in 2017 it reached 115 billion euros. In companies, the economic crisis was exacerbated by declining orders, rising inventories, a lack of investors and a reduction in staff (Worthington \& Britton, 2006) As for unemployment, from $10.5 \%$ in 2009 it climbed to $21.10 \%$ in 2017 (OAED 2018 ). The turnover of the ten largest supermarket chains in Greece in 2012 was 12.3 billion and in 2017 fell to 10.99 billion. (Nielsen). Also, the recession forced to bankruptcy few key players in the market like the Atlantic supermarkets, the withdraw from the Greek market of major foreign companies like Aldi, Plus and Dia and the acquisition of some strategic (along with some small-sized) market chains like Veropoulos, Marinopoulos and Arvanitidis. The crisis was characterized by two negative changes, the first being the sharp reduction in demand and the second is the rapid increase in uncertainty (Hausman \& Johnston, 2014; Wan \& Yiu, 2009).

As shown in surveys, total sales (market size) of the supermarket and cash \& carry companies in Greece, after a continuous four-year decline (2010-2013), exhibited a marginally positive change of $0.6 \%$ in 2014 . However, in 2015 , the market returned to negative growth rates and restricted by $1.6 \%$, a downtrend that continued in 2016 . The supermarket and cash \& carry sector includes a large number of companies, the largest of which control well-known and established retail chains. Competition between companies is particularly intense, given the country's financial situation, which has led to a shrinking of household disposable income. In terms of the sector's concentration, four major retailers accounted for about $50 \%$ of total sales in 2016 . An important role in the trend of increasing concentration in recent years has been the continuous expansion of the largest branch network industry chains, by acquiring stores in other companies and/or by opening new outlets. The majority of stores in the ten largest chains are located in Attica (43.6\%) followed by the Region of Central Macedonia (19.8\%).

Based on the published financial data of the companies, the total sales of 57 companies in the sector increased marginally in $2015 / 2014$, while gross profit increased by $2.1 \%$. The significant increase in operating expenses led to the reversal of operating results from positive in 2014 to negative in 2015. As a result, losses were reported in 2015. It is noted that the results of the consolidated balance sheet are significantly burdened by the size of a company. Besides, the final result of the remaining 56 companies is profitable for both years (2014: $€ 130.6$ million, 2015: $€ 129.7$ million). (ICAP 2017)

According to a survey by the Consumer Goods Retail Research Institute based on data from the Hellenic Statistical Service (HelStat), it appears that food retailing amid a severe economic downturn is one of the few sectors of the economy that has sustained and increased employment in Greece. According to the employment data provided by the HelStat (2017) quarterly, the food retail trade increased by $7.4 \%$ in the 6 years $2010-2016$, as opposed to the total retail trade which decreased by $3.8 \%$ and overall with the Greek economy that was also decreased by $13.5 \%$. Practically, the food retailer in 2016 employed 13700 more employees than in 2010, approaching 200000 direct employees. Specifically, in 2016 , the food retail sector increased its employment by $2.7 \%$ compared to 
2015 (5300 employees), and also overall retail trade also increased in 2016 by $0.7 \%$, compared to 2015. Due to the increase in the food retail trade over the last 6 years and the simultaneous decline of other retail sectors, food retail employment now represents almost $30 \%$ of total retail and wholesale trade, with significantly higher sales than the rest. At the same time, while direct employment in the food retail trade in 2010 represented the $4.37 \%$ of the Greek labour market, in 2015 it represented 4.88\%, surpassing sectors such as the Construction, Banking, Transport and Health. (ELSTAT 2017 super-market)

Concerning the quality of employment in the supermarket sector, it is noted that supermarket chains offer employment to groups of the population most affected by unemployment and who face greater difficulties in finding employment, such as young people, unskilled employees and women. It should also be noted that the sector's contribution to tackling unemployment in the regions, as the chain sales networks are not limited to urban centres or industrial areas of the country but cover the whole territory. Supermarket chain personnel account for $65 \%-70 \%$ of women, while more than two-thirds of chain stores operate outside the country's major urban centres.

This increase in employment in the food retail sector is due to several factors. Purchases and mergers have led the new larger companies to hire staff who were unable to make smaller ventures. At the same time, in the overwhelming majority of companies leaving the market, corporate stores were not closed but continued to operate under new administrations. Another factor is the development of new companies in the sector, either in new sales channels such as online supermarkets or in specialized channels such as delicatessen, speciality shops with Greek products, traditional shops with tourist character (IELKA: New employment growth in food retail in 2017.). Also, a significant determinant was the development of retail food chain networks in the first years of the economic downturn in 2010-2014 (mainly new supermarket chains from the large and medium-sized chains of the sector) as well as the upgrade of the network with new technologies, systems and innovative processes of service. These well-developed networks are also generating new investment in network organization, computerization and maintenance to increase the productivity of companies, which in turn generate new needs for highly qualified personnel. Furthermore, large companies in the industry have been recognized and rewarded repeatedly for the working conditions they provide for their staff as well as their best practices in human resource development. According to the data of IELKA (2015), it turns out that food retailing during a severe economic downturn is one of the few sectors of the economy that maintains employment in Greece, with about 190,000 jobs.

Bearing the aforementioned, the objective of the current study is to analyze the financial statements of retail companies for the years of 2012 to 2017 and to employ ratios to obtain information on the proper management of financial resources within the company. The sample consists of the major actors in terms of turnover, in the food retail sector, namely $A B$ Vassilopoulos SA, Masoutis SA and Sklavenitis SA. The turnover for these chains in 2017 was, for AB 2.091 million EUR, for Masoutis at 761. million EUR and for Sklavenitis at 1.384 million EUR. To achieve the objective of the study, a comparative analysis was employed via the financial indicators of Activity, Efficiency and Liquidity. The choice of the particular economic sector was based on the fact that it represents the $5 \%$ of the total country's employment, leaving behind other economic sectors like the construction, transportation, banks and even the health sector. The study points some significant implications for i) potential shareholders, who may have any investment interest, 
ii) creditors or suppliers, who are interested in the profitability along with short and long term viability of the company, to determine the amount of credit, the borrowing rate and the collateral required by the company, iii) the company's management to make an investment financial or operating decision and iv) the company to know its viability (Soubeniotis \& Tampakoudis, 2015; Katsanidis, 2005).

\section{Materials and methods}

The income statement indicates the profitability of the company for a given period, where the net income is calculated by subtracting all expenses from income. The report provides information on transactions that have taken place within an accounting period. The expenses included in this statement of earnings are purchases, administrative expenses, sales expenses, profit tax and depreciation (Soubeniotis \& Tampakoudis, 2015). Initially, the gross profit is calculated by subtracting the cost of sales from net sales, that is the sum of the labour costs, the cost of sales, and the raw materials for the goods sold in that period. Afterwards, the operating income is calculated (Kantzos 2002), where depreciation, sales and administrative expenses are deducted from gross profit. The earnings before taxes come if extraordinary expenses and interest are deducted from the operating income, and the tax is then calculated as a percentage of the profits and deducted so that we arrive at the net profit. The income statement is, therefore, the first publication with explanatory dimensions for the economic results, since it summarizes all the revenue and expenditure movements of the entire accounting year.

As far as the financial analysis is concerned, it is called the exploration and exploitation of the data we derive from the company or financial statements of the companies, that is, tables showing information about the financial position of the company (Vassiliou \& Heriotis 2008). A key source of information for a company is the two key accounting statements, the Balance Sheet and the Income Statement (Kantzos 2002). Financial statements are used to evaluate a company's financial position and performance and their proper analysis assist investors to obtain useful information so that they can arrive at the optimal investment (Gikas 2002).

Accordingly, a financial ratio is the arithmetic result of the division of one financial asset into another and used to express the relevance of the various financial variables. The principal statements from which these data are derived are the balance sheet and the income statement (Soubeniotis \& Tampakoudis, 2015). Ratios are simply an instrument that facilitates the comparison between the amounts presented in the financial statements, and they are considered to be one of the main tools in financial statement analysis, as they assist the researcher to present the financial statements data in a concise and comprehensible way. By combining those amounts that could, in comparison, become a source of information for the researcher, the ratios give a concise picture of the past, present and future of the company being examined (Vassiliou \& Heriotis 2008).

It is worth mentioning that the ratios are interdependent and should be considered as a whole. The analysis of a financial situation with ratios should not examine ratios individually but compare them over time with the corresponding ratios of other companies in the industry (Soubeniotis \& Tampakoudis, 2015). Besides, analyzing the financial statements of a company with ratios requires particular consideration, since they simply help the researcher to identify whether the company has a problem, without providing a 
solution to it. In particular, in analyzing the financial statements with ratios it is good to adhere to the following principles (Gikas 2002) of i) not compare large companies with small companies; ii) not compare companies from different sectors of the economy; iii) not compare financial statements of different companies with different dates; iv) not compare financial statements if the amounts presented therein have been calculated using different accounting methods and techniques, and v) use the ratios with caution and not draw conclusions about the causes of the problems the company presents (Kantzos 2002). The selected ratios used to analyze the financial statements of companies in the retail sector in the current study are presented in the following section.

\section{Liquidity Ratios}

Liquidity is defined as the ability of an economic entity to repay its obligations without disrupting its proper functioning. (Papadeas, \& Sykianakis 2017) For its part, the concept of Short-Term Liquidity expresses the ability of the company to repay its shortterm or even long-term obligations promptly through the disposal of current assets. Because short-term obligations and especially long-term obligations by default are expected to be repaid over a short period, the emergence of a liquidity analysis is primarily located in the short-term. Therefore, when referring to liquidity analysis, the focus is on short-term liquidity.

\section{Working Capital Ratio or Current Ratio}

This ratio indicates how many times the current Assets cover short-term obligations. To be considered fluid, the fraction numerator must be greater than the denominator, that is, the division quotient is greater than the unit. It is hereby implied that the current Assets, after exceeding the Short-term Obligations, will be sufficiently liquid for their repayment. The specific ratio is given by the formula:

$$
\text { WorkingCiapitalKatīo }=\frac{\text { CurrentAssets }}{\text { Shovt }- \text { TermObligations }}
$$

\section{Immediate Cash Ratio}

The particular ratio a more conservative look at a company's ability to cover its debts and obligations, since it takes into account the cash or cash-equivalent holdings, leaving other assets, including accounts receivable, out of the equation. The ration is offered through the formula 1 :

$$
\text { ImmediateCashRatio }=\frac{\text { Cash }+ \text { Cashequivalent }}{\text { Currentobigations }}
$$

The immediate cash ratio comes to address some of the weaknesses of the previous indicator and is considered a more stringent liquidity measure than Indirect Liquidity (Grigorakos,2011).

\section{Cash Flow Ratio}

This ratio is similar to the previous two, but it is also the most stringent liquidity measure. Its numerator only includes cash and securities, not stocks and receivables 
whose liquidation may be delayed under certain conditions. Securities (stocks, bonds and some financial - investment products) are considered liquid assets, especially if they are traded on a stock market. The denominator of the ratio does not differ from the denominator of the instant liquidity ratio. It is offered by the following formula (2):

$$
\text { Cashflowratio }=\frac{\text { Debt+Available }}{\text { Short-term obligationa }}
$$

\section{Activity Ratios}

Activity or otherwise working capital ratios show how quickly or slowly stocks are updated, customer claims are collected, and obligations are paid to an entity's suppliers. The effective collection of receivables, the repayment of short-term obligations and the renewal of inventories are largely related to a company's liquidity.

\section{Stock Turnover Ratio}

This ratio displays how many times the unit's marketable inventories are recycled in use, i.e. converted into customer balances and from there into cash or bills and again into stocks (how much time is needed to liquidate stocks). It is used also and in combination with the previously mentioned liquidity ratios to better assess the unit's liquidity and credit and borrowing capacity. It also serves internally for evaluating the performance of the company's sales and inventory management policy from its respective departments and externally for evaluating the quality of stocks specifically in a bank substock decision. Studying the evolution of the ratio over time can lead to conclusions on whether or not to improve the market position of the company. The particular ration is given from the following formula (3):

$$
\text { StockTurnoverRatio }=\frac{\text { costofsold }}{\text { Averagenventory }}
$$

\section{Receivables Turnover Ratio}

It exhibits the number of times the balances in the "Receivables" account are recycled and helps evaluate the above liquidity ratios (time required to collect/liquidate these balances). Complementary and in combination with the liquidity ratios it can be used to better assess the unit's liquidity and credit and borrowing capacity. It is also useful in evaluating the performance and sales and credit policy of the company's customers, as well as in the factoring decision of other company's customers. This ratio also reflects the credit policy of the company towards its clients or potential clients, but also to its competitors in general and can be given from the following formula (4):

$$
\text { ReceivablesTurnoverRatio }=\frac{\text { Netsales }}{\text { Receivables }}
$$

\section{Short-term Obligation Turnover Ratio}

The short-term turnover ratio indicates how many times a company is paying its obligations to its suppliers. It also expresses the credit policy of the company to its suppliers. Based on this ratio we can calculate the number of days a company delays paying its suppliers. The more days are better because in this way the cash remains longer 
in its cash register, so it can use it efficiently in its other activities but also increase its liquidity. The specific ration is calculated based on the formula (5) below:

$$
\text { Short }- \text { term ObligationTurnoverRatio }=\frac{365}{\text { Short-Termobligations }}
$$

\section{Results}

The analysis of the different rations explained in the methodology offered significant insights for the operation and the financial status of the major actor in the Greek retail sector. More specifically, for the retail chain $A B$ Vasilopoulos $S A$, it is obvious (Table 1) that the General Liquidity Ratio averages 0.63 through the years of the study. This is acceptable since the values refer to the supermarket and are due to the high speed of inventory traffic. Compared to the year 2013, it is clear that the company with a ratio of 0.73 was in a better financial position than the rest of the years.

Table 1 Liquidity Ratios for AB Vasilopoulos SA

\begin{tabular}{|l|l|l|l|l|l|l|}
\hline Liquidity Ratios & 2012 & 2013 & 2014 & 2015 & 2016 & 2017 \\
\hline General Liquidity & 0,70 & 0,73 & 0,65 & 0,56 & 0.57 & 0.54 \\
\hline Immediate Liquidity & 0,17 & 0,33 & 0,33 & 0,27 & 0.31 & 0.27 \\
\hline Cash Liquidity & 0,17 & 0.33 & 0.25 & 0.19 & 0.21 & 0.16 \\
\hline
\end{tabular}

The instant cash ratio indicates that the company has very low liquidity since the ratio is lower than the unit, and 2012 was the lowest value of 0.17 , followed by an average of 0.30 for the next years. This means that the company is unable to meet its current obligations. The company appears to be dependent on its future sales to ensure sufficient liquidity. So, if there is a decline in sales, the company should seek new capital, either by issuing new shares or by lending. (Niarchou, 2004). The Cash Flow Ratio also fluctuates at very low prices for all the six years under study. According to these results with an average value of 0.22 , it seems that the company is unable to meet its obligations using only the cash of its fund or its sight deposits.

Table 2 Working Capital Ratio for AB Vasilopoulos SA

\begin{tabular}{|l|c|c|c|c|c|c|}
\hline Working capital ratios & 2012 & 2013 & 2014 & 2015 & 2016 & 2017 \\
\hline $\begin{array}{l}\text { Stocks } \\
\text { (in days) }\end{array}$ & 12.97 & 11.89 & 10.93 & 10.41 & 10.75 & 10.92 \\
& $(28)$ & $(30)$ & $(33)$ & $(35)$ & $(34)$ & $(33)$ \\
\hline Requirements & 13.55 & 36.03 & 37.58 & 33.69 & 34.87 & 28.35 \\
(in days) & $(27)$ & $(10)$ & $(10)$ & $(11)$ & $(10)$ & $(13)$ \\
\hline $\begin{array}{l}\text { Short-term obligations } \\
\text { (in days) }\end{array}$ & 3.09 & 3,37 & 3,10 & 2,83 & 2,79 & 2,761 \\
\hline
\end{tabular}


Table 2 above exhibits that the company has a relatively stable capital turnover ratio and does not exceed 35 days. By far the best year was 2012 with 28 days. Generally, the fewer days the stock is recycled, the better for the company because it sells faster, which results in the goods being converted into cash. On the receivables, we observe that after 2012, when the collection days were 27 , a huge effort was made on their part and the days of the last five years to be on average 10.8 days, that is a very good value, increasing the company's liquidity so that it can meet its obligations. Short-term Obligations to suppliers are observed to be paid in 122 days on average, compared to 10.80 days on the speed of receivables. This denotes that the company follows an effective payment and receivables policy and therefore does not require large amounts of current assets to pay its short-term obligations since these can be covered by receivables. It also shows us that suppliers provide the company with a great deal of time to pay its obligations since the company is one of the three most significant customers.

According to Table 3, the gross profit has stabilized to $25 \%$ in 2017 after a low in 2012 , indicating that the company has managed to keep this ratio stable for the last four years. This means that the company sells its final product at a gross profit of around $25 \%$ during the last 4 years, which is positive for the operation of the company and the increase in gross profitability. As for the net profit ratio, we can see that, except for 2016 when it reached 3.24, it fluctuates at low levels with an average of 2.66. This is due to high operating costs and board fees combined with the intense competition. Lastly, in the total capital ratio, only the accounting years 2014 of 2016 and 2017 exceeded 5 points with the most efficient year being 2017 with a value of 6.57 . The returns on the company's total assets are in line with the net profit indicators as you will see in Table 3.

Table 3 Efficiency Ratios for AB Vasilopoulos SA (\%)

\begin{tabular}{|l|c|c|c|c|c|c|}
\hline \multicolumn{1}{|c|}{ Efficiency Ratios } & 2012 & 2013 & 2014 & 2015 & 2016 & 2017 \\
\hline Mixed profit & 22,24 & 24.65 & 25,22 & 25,13 & 25.10 & 24.97 \\
\hline Net profit & 2.30 & 2,29 & 2,88 & 2,54 & 3,24 & 2,72 \\
\hline Total funds & 4.32 & 4.46 & 5.56 & 4.76 & 6.57 & 5.34 \\
\hline
\end{tabular}

As we can see from Table 4, General Liquidity Ratio for the company Masoutis SA is at the levels of $A B$ Vasilopoulos levels as well with a value of 0.60 , except for 2017 which fell to 0.55 . In the instant liquidity ratio, we can see that except for the years 2012 and 2016, values are also moving at low numbers with an average of 0.19 . At the same low levels is the Cash Flow Ratio, which averaged at 0.14 , indicating that it may endanger the company in a situation of a sudden demand for cash from its creditors. However, it is worth mentioning that the company is a supermarket chain with sales being a cash counter with very little wholesale credit sales. This ratio is a serious indicator of liquidity, but its updating is often "fictitious" because companies have a low level of cash holdings to make scheduled payments. (Sykianakis \& Papadeas 2014). 
Table 4: Liquidity Ratios for Masoutis SA

\begin{tabular}{|l|c|c|c|c|c|c|}
\hline Liquidity Ratios & 2012 & 2013 & 2014 & 2015 & 2016 & 2017 \\
\hline General Liquidity & 0,63 & 0,60 & 0,61 & 0,58 & 0.63 & 0.55 \\
\hline Immediate Liquidity & 0,24 & 0,16 & 0,17 & 0,17 & 0.24 & 0.16 \\
\hline Cash Liquidity & 0,10 & 0.11 & 0.13 & 0.15 & 0.21 & 0.12 \\
\hline
\end{tabular}

To achieve the objective of the study, a comparative analysis was employed via the financial indicators of Activity, Efficiency and Liquidity. The choice of the particular economic sector was based on the fact that it represents the $5 \%$ of the total country's employment, leaving behind other economic sectors like the construction, transportation, banks and even the health sector. The study points some significant implications for i) potential shareholders, who may have any investment interest, ii) creditors or suppliers, who are interested in the profitability along with short and long term viability of the company, to determine the amount of credit, the borrowing rate and the collateral required by the company, iii) the company's management to make an investment financial or operating decision and iv) the company to know its viability (Soubeniotis \& Tampakoudis, 2015 Katsanidis, 2005).

Table 5: Working Capital Ratio for Masoutis SA (in days)

\begin{tabular}{|l|c|c|c|c|c|c|}
\hline & 2012 & 2013 & 2014 & 2015 & 2016 & 2017 \\
\hline Stocks & & & & & \\
(in days) & 6.29 & 6.81 & 6.87 & 6.91 & 6.90 & 6.50 \\
\hline Requirements & $(58)$ & $(54)$ & $(53)$ & $(53)$ & $(53)$ & $(56)$ \\
(in days) & 10.67 & 18.48 & 21.03 & 20.26 & 20.54 & 22.39 \\
\hline Short-term obligations & $(34)$ & $(20)$ & $(17)$ & $(18)$ & $(18)$ & $(16)$ \\
(in days) & 1.92 & 2.26 & 2.30 & 2.05 & 1.98 & 2.05 \\
& $(190)$ & $(161)$ & $(158)$ & $(178)$ & $(184)$ & $(178)$ \\
\hline
\end{tabular}

As for the efficiency ratios for the company Masoutis SA, Table 6 indicates that the gross profit ratio is almost constant at an average level of $22.63 \%$ designating that there is a stable policy to be followed. It is also clear the upward trend existing in the percentage of net profit after 2013, reaching 2.52 in the last four years, showing the change to the company's goal, meaning that it does not have a long way to go in increasing the ratio, reducing its operating and administrative expenses. In the ratio of total funds, although there is great competition in the retail sector, for Masoutis it is evident that after 2013, the last four years with an average of. 3.78 shows an increase in the ratio of earnings before taxes and interest to its total assets. 
Table 6 Efficiency Ratios for Masoutis SA

\begin{tabular}{|l|c|c|c|c|c|c|}
\hline \multicolumn{1}{|c|}{ Efficiency Ratios } & 2012 & 2013 & 2014 & 2015 & 2016 & 2017 \\
\hline Mixed profit & 22.16 & 22.20 & 22.30 & 22.48 & 23.40 & 23.27 \\
\hline Net profit & 1.59 & 1.18 & 2.22 & 2.23 & 3.14 & 2.52 \\
\hline Total funds & 2.23 & 1.78 & 3.34 & 3.32 & 4.69 & 3.78 \\
\hline
\end{tabular}

The third most important player in the Greek retail sector, according to market share data, is the company Sklavenitis SA. The assessment of the company's financial statements for the years 2012 to 2017 reveals that the general liquidity ratio is not an exception compared to its rivals, as it remains at an average value of 0.57 (same low levels as $A B$ Vasilopoulos averaged 0.63 and Masoutis who averaged 0.60 ) and it is also lower. According to the extant literature, the value of the liquidity ration should be between 1 and 2, which means in our case that the studied companies have very low liquidity (Sykianakis \& Papadeas 2016),

Table 7: Liquidity Ratios for Sklavenitis SA

\begin{tabular}{|r|r|r|r|r|r|r|}
\hline Liquidity Ratios & \multicolumn{2}{|c|}{2012} & 2013 & 2014 & 2015 & 2016 \\
\hline $\begin{array}{l}\text { General } \\
\text { Liquidity }\end{array}$ & 0,55 & 0,50 & 0,56 & 0.65 & 0.59 & 0.61 \\
\hline $\begin{array}{l}\text { Immediate } \\
\text { Liquidity }\end{array}$ & 0,22 & 0,12 & 0,12 & 0,27 & 0.27 & 0.26 \\
\hline $\begin{array}{l}\text { Cash } \\
\text { Liquidity }\end{array}$ & 0.11 & 0.09 & 0.09 & 0.18 & 0.18 & 0.06 \\
\hline
\end{tabular}

For the same period, the direct (or special) liquidity of Sklavenitis is approximately 0.21 , indicating that the company can cover the short-term obligations if it liquidates its current assets outside its reserves. The highest liquidity appears during the last three years as it can cover $26.6 \%$ of its obligations. If we consider that a good ratio is near unity, it is clear that the company is also not characterized by its liquidity. The latest Liquidity Ratio is Cash Flow liquidity. The Sklavenitis can cover by using the cash and cash equivalents of an average. 0.12, the lowest of the three (3) comparable companies. The Cash Flow Ratio can put the company at risk if its creditors suddenly demand cash. As for the working capital ratio, it is obvious from Table 8 that for the six years the company renews its inventories by 47 days. The shorter the days it refreshes the better as it sells faster. The results may be because the company is a supermarket chain with large rooms and large inventory required. According to the requirements ratio, except for 26 days in 2017 , in previous years it was very low at an average of 12 days. All of the above are based on each company's sales policy and payment policy. At this point, it is worth mentioning that the completion of a sale is done by paying it off. According to the supplier capital ratio, for the six years, Sklavenitis repays its suppliers within an average of 148 days. The longer the days the company needs to pay its obligations the better. It takes on 
average about five months to pay off the obligations to its suppliers, from the day they are created, compared also with the amount of time it takes to receive claims from its customers, which is 14 days. Based on the above, we conclude that the company policy is good enough because the money stays in the 'fund' for about four and a half months and can use it or reinvest it in other activities or cover some other obligations.

Table 8: Working Capital Ratio for Sklavenitis SA (in days)

\begin{tabular}{|l|c|c|c|c|c|c|}
\hline Working capital ratios & 2012 & 2013 & 2014 & 2015 & 2016 & 2017 \\
\hline $\begin{array}{l}\text { Stocks } \\
\text { (in days) }\end{array}$ & 9.24 & 7.43 & 6.97 & 7.31 & 7.56 & 7.93 \\
\hline $\begin{array}{l}\text { Requirements } \\
\text { (in days) }\end{array}$ & 39 & 49 & 52 & 50 & 48 & 46 \\
& 15 & 58.40 & 32.17 & 30.74 & 23.88 & 14.01 \\
\hline $\begin{array}{l}\text { Short-term obligations } \\
\text { (in days) }\end{array}$ & 25.05 & 11 & 12 & 15 & 26 \\
\hline
\end{tabular}

Finally, as regards the efficiency ratios for Sklavenitis, Table 9 reveals that the gross profit margin for Sklavenitis is approximately $24.74 \%$ to a low of $23.29 \%$ in 2017 . The decrease by $2 \%$ between 2016 - 2017 may be due to the fierce competition in the sector. In the net profit ratio, it is obvious that it started low, below unity in 2012, and exceeded in 2015 to two points in 2016 and slid to 0.79 in 2017. An alarming turnaround throughout the studied years, at low rates and without stability. This may be because all the negative results that the company exhibits are due to the highly competitive operational environment, and the fact that in the current period a new map of market shares is developing in the retail sector in Greece. As for the total funds' ratio that shows the relationship of earnings before taxes and interest with the total assets of the company, it is also at low levels with net profits and is at an average value of $1.78 \%$. Here again, it is worth mentioning that all three companies operate in a fully competitive environment and therefore achieve a low return on total assets as profit margins are determined by competition and therefore cannot be maintained at high levels.

Table 9: Efficiency Ratios for Sklavenitis SA

\begin{tabular}{|l|c|c|c|c|c|c|}
\hline \multicolumn{1}{|c|}{ Efficiency Ratios } & 2012 & 2013 & 2014 & 2015 & 2016 & 2017 \\
\hline Mixed profit & 24.83 & 24.84 & 25.08 & 25.18 & 25.22 & 23.29 \\
\hline Net profit & 0.95 & 0.87 & 0.79 & 1.48 & 1.93 & 0.79 \\
\hline Total funds & 1.56 & 1.40 & 1.28 & 2.32 & 3.03 & 1.13 \\
\hline
\end{tabular}

\section{Conclusion}

The results of the indicators indicate that all three major companies in the Greek retail sector have low results in almost all comparable indicators, mainly due to the intense competition coupled with the economic crisis. The first and biggest negative impact of the economic crisis is on the disposable income that most supermarkets absorb. Accordingly, 
to survive, supermarkets have tried to have as little absolute losses as possible, losing some of the units in the profitability indicators mentioned above. Strong promotions were extremely supportive as they helped consumers, as well as retailers and their suppliers, cope with difficult times of crisis.

Returning to the major actors in our study and bearing in mind the general liquidity ratios, its prices are acceptable since these companies are retailers and their market repayment in cash and payment of bills is up to 190 days. At the same level is the immediate liquidity which means that if they do not meet their obligations, they will either raise their funds or borrow money; the latter being very difficult in the middle of an economic crisis. Cash liquidity is no exception and it is consistent with the above liquidity ratios. The reason why the studied companies $A B$ Vasilopoulos, Masoutis and Sklavenitis survive and respond with consistency and stability in their obligations is that they regulate their liquidity needs by closely monitoring their debts and obligations. The liquidity ratios are checked regularly, on a daily, weekly, monthly, semiannual and yearly basis, to always meet the obligations. This is a great effort by corporate executives and what you find is that they are doing so even in these difficult times, by keeping their company away from liquidity risk and having enough money. This ratio is a serious indicator of liquidity, but its updating is often "fictitious" because companies have a low level of cash holdings to make scheduled payments. (Sykianakis \& Papadeas, 2014).

In the activity ratios and in particular, in the stock ratio, we can see that the company $A B$ Vasilopoulos has the best management with 32 days on average. This means that within 32 days the commodity is converted into cash, with the companies of Sklavenitis and Masoutis followed by 47 and 54 days respectively. Faster renewal of goods not only brings quick cash to the existed capital but also reduces expired returns (most of the goods are consumables with a short expiry date) and reduces the deterioration and disaster brought about by their prolonged storage time - sale on the supermarket shelves.

In the Receivables Ratio, each company's collecting policy has been assessed. The faster the receipt of receivables the more you achieve the increase in cash liquidity and most importantly, the less you reduce the loss of doubtful customers. Except for Sklavenitis, which, while fluctuating 11 days for the years 2013-16, exits at 26 in 2017, the other major changes were made by the two companies AB Vasilopoulos and Masoutis, which, in 2012, were 27 and 34 days respectively collecting revenue, they ended up with 13 and 16 days respectively in 2017. As regards the short-term obligations ratio, all companies monitor the receivables ratio, so it does not exceed (in days and value) the short-term obligations ratio. The timing of payment of obligations to suppliers is commented on in a variety of ways. Positive when the days are many because the fund is likely to be invested in the more profitable activity, but even worse when there are many days because a degree of 'dependence' on the supplier is created. Negative, if in a possible change in the supplier's collection policy, it may bring instability to the borrower's finances; "the customer who pays in cash gets the best benefit". Suppliers know their customers and want this partnership to be healthy and this is done by constantly monitoring their customers' financial ratios. In the short-term obligations, the comparison between the companies exhibits that $A B$ Vasilopoulos repays its suppliers in 122 points days, faster than the second Sklavenitis who pays in 148 days and Masoutis who pays on an average of 174 days. 
As for the Profitability Ratios, it is clear that the studied companies display different strategies for different amounts, values, sizes, but with a common goal that is profit; often low but positive. In the gross profit ratio, since it shows the relationship between gross profit and sales, we find the percentage gross profit margin with which the firm sells its goods. Greater cost savings are present if it has high values. There is also the possibility that the low gross profit margin will generate high profits, subject to the following conditions: $i$ ) the company has a zero-ratio receivables ratio (so it sells the goods at the counter); ii) the stock turnover rate tends to zero; iii) the short-term obligations ratio (suppliers) to be 'proportionally' to the ratio as well as its profits. A high arithmetic gross profit demonstrates the management's ability to buy cheaply and sell at competitive prices, but with high profitability, meaning that the company has an effective pricing policy. The decrease in the gross profit may be due to the price policy set by each company in combination with the reduction of disposable income (financial crisis) and intense competition. Accordingly, in the gross profit ratio, $A B$ Vasilopoulos with an average of $25.11 \%$ and Sklavenitis with $24.74 \%$ have the highest percentages, followed by Masoutis with $22.64 \%$, always based on each strategy - policy each company follows.

The net profit ratio attracts the interest of investors, banks, suppliers, shareholders, company personnel since it shows the percentage remaining in the company if you subtract off the net sales the cost and other expenses. The net profit margin should be compared to the gross profit margin and a high net profit ratio shows high profitability. The ratio highlights the ability of the company's management to handle difficult financial situations, such as inadequate customer visits, small value shopping carts, intense competition, etc. The analysis of the particular ratio requires examining the investments, capital, surveillance and not just sales. However, the size of the company should also be taken into consideration since a stable percentage of the ratio brings about different results in different sized companies. One way to improve the low net profit ratio is to reduce operating and administrative costs, not necessarily by lowering employee salaries. There is not a single operating component of a company that cannot be improved and possibly reduced in cost.

The results of the study show that $A B$ Vasilopoulos led the net profit margin with an average rate of $2.67 \%$ and reaching $3.24 \%$ in 2016 , followed by Massoutis with $2.15 \%$ (with a better year in 2016 of $3.14 \%$ ) and finally, Sklavenitis with a low of $1.14 \%$. The results may be low, but still positive. Finally, the ratio of total funds shows the degree of utilization of total funds (own and shareholders) and foreign capital (supplier credits, bank loans, creditors, etc.) that each company generates from them net profit, regardless of their contribution rate, between equity and foreign capital. The increase in return on investment is in line with the increase in equity. An increased investment with a low return may be the cause of a low overall return on equity. It is worth mentioning that the primary objective of any company is to achieve the goal, which is none other than the investment that made is profitable. The highest and best return on total funds on average is exhibited by $A B$ Vasilopoulos with5.17\%, with slight fluctuations per year, with the best performance in 2016 at $6.57 \%$. Masoutis follows with $3.19 \%$ after the stability of the last four years and with a 'stronger' the year of 2016 with $4.69 \%$. Finally, with a low average of $1.79 \%$, Sklavenitis is at the last place, with its best year in 2016 where the company reached $3.03 \%$. It seems that the year of 2016 was when the studied companies had the highest return. As a result, the companies changed their policy on operating expenses, reduction 
of operating costs, investment, competition, streamlining of stores, pricing policy, profit margins (reduction), pumping customers from other channels (fresh bread, ready meals, coffee, fresh juices, etc.) reduction of stocks and reduction of (day) receivables.

Conclusively the large chains proved resilient to a declining market and maintained - or even increased - their sales against smaller businesses, which suffered significant losses. This fact is attributed to the investment activity of large players in the field of organic development and acquisitions, in the exploitation of economies of scale and in the implementation of strategies to mitigate the effects of the recession (discount and bid policy, private label products). Also of concern is the retention of operating costs, which has been reflected in the stimulation of profitability in recent years. In this context, these chains are implementing investments in automated warehousing and warehousing systems, knowhow, and various infrastructures, to achieve a reduction in long-term costs.

The market for organized retail is growing more and more through an aggressive supply and discount strategy, which is now a permanent part of supermarket policy to keep the downward trend in sales and attract consumers. In this area, the big chains have a competitive advantage over the smaller companies in the market, which - not being able to compete with the price competition - are faced with the possibility of either shutting down or merging with other competitors. A key parameter if the large players in the market are the organic development and the network expansion through acquisitions of smaller and not just chains.

\section{References}

Beaver, W., 2002. Perspectives on recent capital market research. The Accounting Review, Vol. 77, No. 2, pp. $453-474$

Gikas C.D. 2002. The analysis and uses of accounting statements. Publications Benou C. Athens Grigorakos, G. T. 20011. Analysis - Interpretation of the General Accounting Plan ed. - Athens: Sakkoulas Ant. N., 2011

Hausman, A., and Johnston, W. J. (2014). The role of innovation in driving the economy: Lessons from the global financial crisis. Journal of Business Research, 67(1), 2720-2726

Kantzos K. 2002. Financial Statement Analysis, Interbooks Publications - Athens.

Katsanidis, S. 2005. Financial operations. Department of TEI Publications of Thessaloniki.

Koufaris G., 2010, The global economic crisis and the stock markets. Money Magazine, JanuaryFebruary 2010.

Mankiw N. G. 2013. Defending the one percent. The Journal of Economic Perspectives, 27(3), 21-34

Niarchou, and Nikitas. 2004, Financial analysis of accounting statements, Publications. Stamouli, Athens.

Papadeas P and Sykianakis N, "Analysis and Investigation of Financial Statements". Papadea Publications, Athens, 2017, page 70

Soumpeniotis, D. and Tampakoudis, I. 2015. Financial Analysis, Thessaloniki: SoumbeniotisTampakoudis Publishing House

Sykianakis, N. and Papadeas, P. 2014. Analysis and investigation of Financial Statements with Greek and International (Accounting) Financial Information Standards. Athens: Publication of the same.

Vassiliou D. and Heriotis N, 2008, Financial Administration, Publisher: Rosili, Athens.

Wan, W. P., and Yiu, D. W. (2009). From crisis to opportunity: Environmental jolt, corporate acquisitions, and firm performance. Strategic Management Journal, 30(7), 791-801. 
Worthington I. and Britton C. (2006) The Business Environment. 5thEd., Pearson Edu-cation Limited, Harlow, Essex, UK.

\section{Institute - statistical services}

ELSTAT, Consumer Goods Retail Research Institute. Jobs: 13,700 recruitments in supermarkets! https://www.neolaia.gr/2017/05/11/ergasia-13700-proslipseis-sta-super-market

ELSTAT, Consumer Goods Retail Research Institute, https://www.statistics.gr/statistics/eco

ICAP: The course of the Super Markets industry in the Greek market. Tavoulari N. (2017) https://insuranceworld.gr/38954/eidiseis/oikonomia-politikoi/icap-i-poria-tou-kladou-ton-supermarkets-stin-elliniki-agora/\#respond

IELKA: The contribution of supermarkets is significant, in the midst of the economic crisis. http://www.ielka.gr/,http://www.enikonomia.gr/economy/24508,IELKA-Shmantikh-hsyneisfora-twn-soyper-market-en-mesw-ths-oikonomikhs-krishs.html , 2015

IELKA, (Research Institute of Retail Consumer Goods): New employment growth in food retail in 2017. http://www.ielka.gr/,https://www.capital.gr/oikonomia/3292577/ereuna-ielka -nea-auxisitis-apasxolisis-sto-lianemporio-trofimon-to-2017

Nielsen,https://www.kathimerini.gr/973862/gallery/oikonomia/ellhnikhoikonomia/e3afanisthkan-41alysides-soyper-market

OAED 2018, Summary report, Workforce Employment Organization,http://www.oaed.gr/nea 